\title{
ONLINE WRITING EXCHANGE WITH OVERSEAS STUDENTS: EFL LEARNERS' ERRORS AND PERCEPTIONS
}

\author{
Mushoffan Prasetianto ${ }^{1}$, Rizkiana Maharddhika² \\ Brawijaya University. Jl Veteran, Malang, East Java 65145, Indonesia \\ ${ }^{1}$ m.prasetianto@ub.ac.id \\ ${ }^{2}$ r-maharddhika@ub.ac.id
}

\begin{abstract}
Writing skill is crucial for non-English students, like agriculture students because students are required to write an abstract of bachelor thesis in English. Nowadays, writing is not only conducted conventionally i.e. using paper and pencil but also using the internet through online writing exchange. Several studies regarding students' writing errors have been conducted but error analysis of agriculture students' writing using online writing is still less researched. To fill this gap, the present study aimed to analyze the types of errors made by agriculture students during joining Online Writing Exchange with Japanese students and students' perception of the Online Writing Exchange program. 137 students' writings were analyzed and identified the error and counted the error. Questionnaires and interviews were used to know students' perceptions. The results showed that there were three types of an error made i.e. mechanical, grammatical, and L1-influence error. Students' perception toward online writing was positive although they face several difficulties. It is noteworthy that different writing media affect students' different writing errors.
\end{abstract}

Keywords: Online writing, Error writing, Agriculture students

\begin{abstract}
ABSTRAK
Keterampilan menulis sangat penting untuk mahasiswa non jurusan bahasa Inggris, seperti mahasiswa pertanian karena mahasiswa diminta untuk menulis abstrak skripsi dalam bahasa Inggris. Saat ini, menulis tidak hanya dilakukan secara konvensional yaitu menggunakan kertas dan pensil, tetapi juga menggunakan internet melalui pertukaran menulis secara online. Beberapa studi tentang kesalahan penulisan mahasiswa telah dilakukan tetapi analisis kesalahan penulisan pada mahasiswa pertanian menggunakan penulisan online masih sedikit diteliti. Untuk mengisi kesenjangan ini, penelitian ini bertujuan untuk menganalisis jenis kesalahan yang dibuat oleh mahasiswa pertanian selama bergabung dengan Pertukaran Menulis Online dengan mahasiswa Jepang. 137 tulisan mahasiswa dianalisis dan diidentifikasi dan dihitung kesalahannya. Kuisioner dan wawancara juga digunakan untuk mengetahui persepsi mahasiswa. Hasil penelitian menunjukkan bahwa ada tiga jenis kesalahan yang dibuat yaitu kesalahan mekanik, gramatikal, dan pengaruh L1. Persepsi mahasiswa terhadap penulisan online adalah positif walaupun mereka menghadapi beberapa kesulitan. Perlu dicatat bahwa media penulisan yang berbeda mempengaruhi kesalahan penulisan siswa yang berbeda.
\end{abstract}

Kata Kunci: Menulis online, menulis kesalahan, mahasiswa pertanian 


\section{INTRODUCTION}

Indonesian learners find difficulties in finding sufficient sources to learn English. Written and oral sources are regularly obtained in the classroom only. In other words, Indonesia learners are barely exposed to an English environment either spoken or written. Consequently, students should struggle to acquire English four skills (listening, speaking, reading, and writing).

Writing is relatively difficult because it involves grammar and vocabulary at the same time. Writing is difficult and complicated. Students must have good knowledge of grammar and rich vocabulary to deliver their idea in written form (Salima, 2012). Writing is barely understood if it has many grammatical errors. Text having grammatical errors was considered bad quality (Johnson et.al, 2017). It possibly destructs readers to read. Moreover, vocabulary choice is also important in writing. Good vocabulary choice can enliven written work.

Writing skill is crucial for non-English students, like agriculture students, because the students are required to write an abstract of bachelor thesis in English. Writing skill is also needed for their professional work in doing business and to get a good IELTS score band as a scholarship requirement. Writing skill is needed for doing international business correspondence (Naghdipour, 2016). Therefore, preparing students with better writing skills is important to concern.

Writing is one of communication in which the writer expresses their idea to the reader. The idea of the writing can be delivered if the composition is written well i.e. error is not frequently found. For students, making an error in writing is undeniable. Error is part of learning. Thus, error analysis is important for the teacher in designing what to teach and how to teach. By knowing error frequently made by the students, the teacher can understand what the student need for writing course. Several studies on error analysis of writing were extensively conducted. The studies conducted in EFL countries such as Turkey (Atmaca, 2016), six countries (Marina and Snuviskinie, 2005), and Algeria (Salima, 2012) utilized conventional writing tasks (i.e. paper and pencil writing task). However, the error analysis of agriculture students' writing using online writing is still less researched. To fill this gap, the present study aimed to analyze types of writing errors made by agriculture students during joining Online Writing Exchange program with Japanese students. The present study differed from previous studies in two ways i.e. it was conducted online and it was conducted in agriculture students which were non-English department students.

The present study aimed to analyze types of errors made by agriculture students during joining Online writing exchange with Japanese students and students' perceptions toward the Online writing exchange program. The implication of the present study is used as a basis for the lecturer in developing teaching materials especially writing. The teaching materials focus more on what aspect of writing that students mostly find difficult and therefore it can be improved to be better. 


\section{LITERATURE REVIEW}

\section{Error Analysis}

Error is part of the language learning process. Error is defined as "a result of lack of knowledge" (Ellis, 1994). "Error considered to be evidence of learning strategies as it builds competence in the target language by regarding the rules of it" (Marina and Snuviskinie, 2005:275). The factors causing error are different grammar between L1 and L2, and lack of knowledge (Dinamika and Hanafiah, 2019). Therefore, it is obvious that learner makes errors in using target language "English" because they are still in the learning process. The error affects the quality of the text. Texts containing several errors are perceived as poorer quality (Johnson et.al, 2017). Error writing is needed to investigate to know frequent errors made by the students. By knowing the frequency of error can help the teacher to know which method is useful (Wilcox et.al, 2014).

Knowing learner's error is pivotal for the teacher to know how far the learners have learned the language. Error Analysis is commonly used to elucidate learner's errors. Error Analysis is defined as a study to analyze learner's errors (Ellis and Barkhuizen, 2005). Error analysis focused on learners and the language (Atmaca, 2016). Error Analysis has three steps: "identifying, describing, and explaining learner's error" (Ellis and Barkhuizen, 2005:51).

Several studies on error writing have been performed. The study compared a pattern of error among Generation 1.5, L1, and L2 learners were conducted. The results showed that the error made by Generation 1.5 and L1 students writing was similar, while L2 students writing had much more error in a wide range of categories (Doolan, 2017). In Turkey, writing errors made by Turkish learners at a tertiary level of education was analyzed. The results revealed that ten categories of errors are made, i.e. preposition, verb, article, sentence structure, punctuation, gerunds, pluralism, possessives, tenses, and word choice (Atmaca, 2016). Preposition $(23,33 \%)$ was the most prevalent error. Several scientific papers written by non-native speakers Lithuania, Latvia, Poland, China, India, and Nigeria - were investigated. They found 10 error types i.e. word form, verb tense and verb form, connectives, subject-verb agreement, article, word order, sentence structure, vocabulary, punctuation (Marina and Snuviskinie, 2005).

\section{Teaching Writing}

Writing, as a written product, encompasses thinking, drafting, and revising (Brown, 2001). Writing delivers the idea of the students. Thus, the students should concern about the clarity of the idea (Nation, 2009). Clarity can be achieved by minimizing errors in spelling and grammar.

The teaching of writing can focus on product and process (Brown, 2001). Product Approach concern with students' final writing products, whereas the Process 
Approach concern with the process of writing. Writing as a product analyzes and assesses students' writing (Fatimah and Masduki, 2017) and should meet the accurate grammar (Brown, 2001). Writing as process concerns on the process starting from pre-writing until re-writing (Brown, 2001). Writing as a product gives benefit to a teacher because the teacher can analyze students' errors. While writing as a process gives advantages for students to learn the writing skill.

\section{Online Writing}

Online instructions are divided into two: asynchronous and synchronous. Asynchronous is delivered in written communication and synchronous are delivered in real-time (Straub and Ill, 2015). Traditional teaching and studying may be complemented by either synchronous or asynchronous online learning. With the simplicity of online instruction, online learning is the option of the lecturer as an alternate teaching tool.

Online learning technology is a web tool facilitating users for doing a task (Said et. al, 2016). Online learning is used as a means to help the teacher make teaching easier. In Thailand, lecturers feel that ICT assists in terms of time efficiency and monitoring students' work (Deerajviset and Harbon, 2014). Online learning provides collaboration and interaction across the country's borders, e.g. online writing.

A study on students' approach toward online writing tasks based on learning style revealed that reflective learners spend more time on the theory section, and active learners spend more time on the case (Waes et.al., 2014). Besides, the learning style did not affect the writing quality. It affected how students focused on the online course section.

A case study on online first-year writing courses was conducted. It found that most students engaged with the course content frequently (Rendahl and Breuch, 2013). In the online course, interaction is also needed. A study revealed that the peer moderator facilitated the discussion initiation, and a small group comforted the students during discussions and enhanced the interaction among students (Virtue, 2017). In the learning process, interaction among students plays an important position.

\section{RESEARCH METHOD}

The setting was in one of the universities in Indonesia. The participants were from the Agroecotechnology study program. The chosen participant were students who took English courses and joined Online Writing Exchange with Japanese students. The online writing exchange is a collaboration program between two universities (i.e. Japan and Indonesia). In this case, about 38 students' writings (taken from 11 senior students and 27 freshmen) were analyzed. 
The Online Writing Exchange program ran for 6 weeks from April to Mei. The program was divided into four stages with different topics. In this study, the primary data taken from all four stages of the initial post were about 152 posts. During the program, students were required to post initial writing under the topic of each stage. Each stage has various lengths of time (i.e. one / two weeks) for students to post at each stage. The topic of stage 1 was introduction; stage 2 was culture and nature; stage 3 was discussion under a common theme; stage four was a local issue. The initial post should meet the minimal number of words. The minimal words were also varied in each stage ranging, at least, from 200 to 250 words.

Every student was given a username and password to log in the website. The students wrote an initial post following the topic of stage one. Moreover, the students can upload a picture to support their posts. The deadline for stage one was one week. After one week, students can write an initial post in stage two. The post was following the topic in stage two. The deadline for stage two was one week. After one week, students can go on to stage three. In this stage, students chose one of three videos uploaded on the website. The post that students wrote was their opinion regarding the video they have watched. The deadline in this stage was two weeks. After two weeks, students can write in stage four. The topic was the local issue. The students can write the issue surrounding them.

This study used content analysis to examine the students' writing errors. First, the Japanese lecturer sent the data (students' initial post) via email. The data was printed and encoded using some different colors of highlighters to make it easier to analyze. The same color was grouped into the same group. The error was identified to know the types of errors and counted to know the number of errors made.

A questionnaire was used to gain students' perceptions. The questionnaire consisted of 10 multiple-choice questions covering students' difficulty, students' interest, and the efficiency of the program. All questions were written in L1 (Bahasa Indonesia), to make students understand the questions well. Since the researcher used an online questionnaire (Google Form), it was easy to gather the responses. It was easily shared with students and they filled out the questionnaire. Another benefit was that the result of the questionnaires was tabulated automatically.

A semi-structured interview was also used to get deeper information from students. 15 questions were prepared in advance and other questions were asked following the interviewee's responses. The interview was conducted in Bahasa Indonesia to make students feel at ease. The interviewees were students who actively wrote i.e. write replies and post. The interview recordings were transcribed and translated into English. 


\section{FINDINGS AND DISCUSSION}

This section elucidates the findings and discussion of the study. It consists of two subsections: students' types of errors and students' perceptions.

\section{A. Learners' Types of Errors}

From the students' online writing (137 writings), it was found that there were 3 categories: mechanical error, grammatical error, and L1-influenced error. Mechanical error is related to typing performance such as punctuation, capital letter, space, lower case, mistype. Grammatical errors cover nouns, articles, sentence structure, run-on sentences, subject-verb agreement, and lack of to be. The mechanical error becomes the prominent error made by the students.

\section{Mechanical Error}

The analysis reveals five types of mechanical errors i.e. punctuation, capitalization, space, lower case, mistype. Common mistakes found in punctuation are adding or removing commas and periods. Sometimes, students not only place a comma in the wrong place but also forget to place a comma in certain cases. At the end of a sentence, students often forget to add a point. Another mechanical error is capital letters. Inline, one of the dominant mistakes is capital letters (Wilcox, et.al, 2014). Among the five types of mechanical errors, Graph 1 below shows that the most frequent errors are spaces. Adding a space after the end of a sentence tends to be forgotten by most students. Punctuation is also in second place after space. Examples of punctuation errors made by students are commas and periods. However, the mistakes that are rarely made by students are lowercase letters. Examples of student mistakes in lowercase letters are "........in this video There is ....". The letter ' $T$ ' in the word "There' here must start with a lowercase letter. Another rare error is mistyping. Students tend to add 1-2 letters or less 1 letter, for example, "agriculture" and "hi".

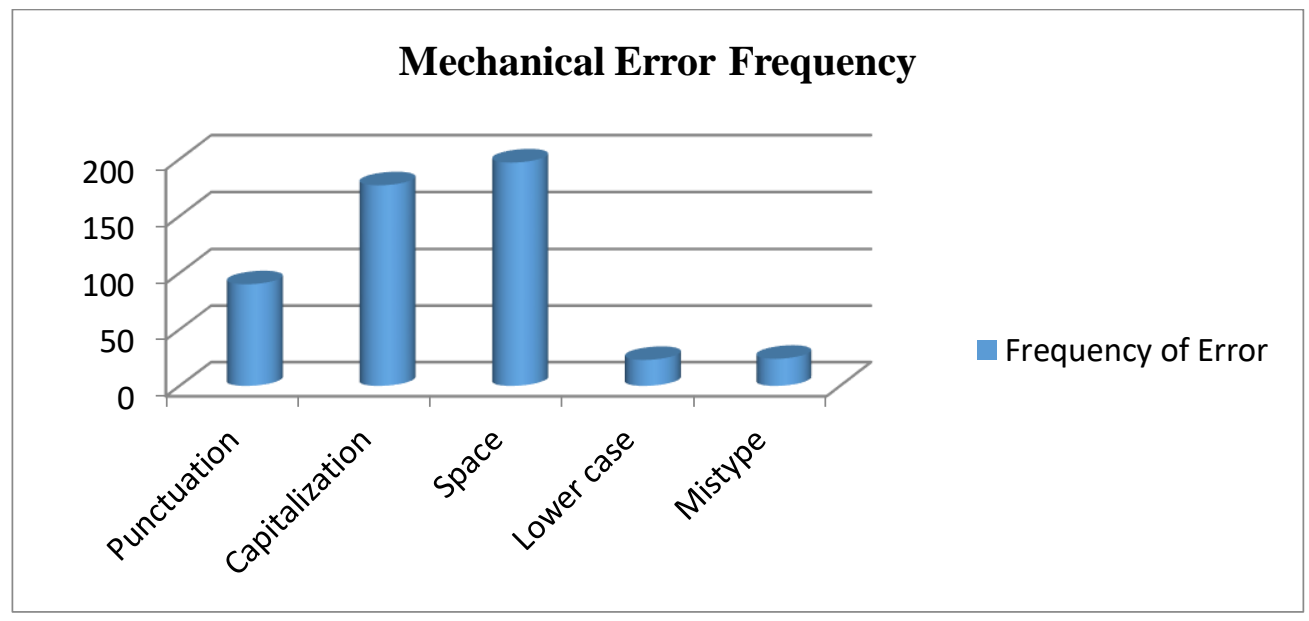

Graph 1. The Results of Mechanical Errors 


\section{Grammatical Error}

Table 1 below indicates that students made 22 types of grammatical errors which account for 254 frequencies. In general, the "Article" error was the prominent grammatical error made by the students and there were 43 errors. Typically, students omit the article for a singular noun.

Table 1. The Frequency of Grammatical Errors

\begin{tabular}{|l|c|l|c|}
\hline \multicolumn{1}{|c|}{ Type of Error } & Frequency & \multicolumn{1}{c|}{ Type of Error } & Frequency \\
\hline Article & 43 & Parallel sentence & 11 \\
\hline Noun & 27 & Conjunction & 5 \\
\hline Lack of to be & 30 & Subject-verb agreement & 17 \\
\hline Pronoun & 14 & Infinitive & 3 \\
\hline Redundancy & 6 & Gerund & 2 \\
\hline Abbreviation & 4 & Modal structure & 5 \\
\hline Present tense & 2 & Preposition & 9 \\
\hline Sentence structure & 42 & Present perfect tense & 3 \\
\hline Compound noun & 6 & Comparison & 2 \\
\hline Pair conjunction & 3 & Past tense & 2 \\
\hline Run-on sentence & 15 & Interrogative & 3 \\
\hline
\end{tabular}

In other studies, Turkish students also made 44 (16.29\%) article errors (Atmaca, 2016). Research papers are written by non-native speakers also made article errors, i.e. definite articles and "a" or "an" for a singular noun (Marina and Sinuviskie, 2005). Article error is not caused by L1 because L1 (Bahasa Indonesia) structure also has an article to refer to a singular noun. It is interesting to investigate further about article error when an L1 structure is the same as an English article. The example of article error made:

a. Cikarang is known as an Industrial city......

b. Social entrepreneurship is people who innovate..........

Noun error had 27 error frequencies. Typically, students often omit $-\mathrm{s}$ for plural because L1 does not have plural formulation ending with $-\mathrm{s}$. This type of error is caused by inter-language. The high-frequency errors made (27 errors) show that students are still unable to use the L2 structure well. They do not know the quantifier which shows plural. They are still in the developmental stage. The students presumably do not aware that one letter in English causes a different function whereas one letter in Bahasa Indonesia does not mean anything and does not change anything. The example of noun error made:

a. You can find many a natural places

b. Indonesia has so many cityiesand every city has its uniqueness 
Lack of "to be" or auxiliary verb account for 30 errors. The errors include an omission of "to be" for an active sentence and a passive sentence. Students omit auxiliary verb for nominal sentence which differs from L1 because L1 does not need an auxiliary verb for a nominal sentence. This difference causes students' error. Furthermore, students exclude "to be" for negative sentence, they directly put NOT in the sentence without putting "to be". The pattern for a passive sentence is "to be + Verb 3". L1 has a passive sentence but the pattern is dissimilar. For passive sentence in L1, the sentence is added prefix $d i$ - for the verb to show passive sentence without adding other words, just prefix. Therefore, students mostly omit "to be" for making a passive sentence in $\mathrm{L} 2$, for example:

a. Desertification is one of the most serious problem nowadays in the world

b. In this video Allan said that desertification is caused by livestock...

Pronoun error accounts for 14 occurrences. The error includes a pronoun "it". The pronoun "it" is used for a thing. While students L1 does not have a pronoun for a thing and is mentioned without a pronoun. Students frequently exclude pronoun "it" in their sentence because of L1 interference.

Sentence structure error accounts for 42 occurrences. Sentence structure error means that the sentence is incomplete consisted of either subject or verb. Students write a sentence without a subject. For example, "it very make me miss my hometown". In another case, students write a sentence without a verb, for example, "re-usable environmental pollution by removing toxic residues both in plants and in the surrounding environment such as water and soil pollution". This error is caused by direct translation from L1 without re-structuring the sentence. Therefore, the sentence structure is incomplete.

The frequency of parallel sentence error is 11 . The errors that students made are unequal structure if conjunction "or" and "and" exists. Students still do not write the equal structure (e.g. part of speech) when conjunction "or" and "and" were applied. Students' L1 do not have an equal structure when "and" and "or" is applied. Thus, the source of error is inter-language because of the different structure of L1. The example of parallel sentence error:

a. This dance is staged about 25-40 dancers and the musicians

b. I love to read a book and tohunghang out with my friends

Subject-verb agreement is still a problem for students. It is shown by 17 error occurrences. In line, it was noticed that subject-verb do not agree in number (Marina and Snuviškiené, 2005; Dinamika and Hanafiah, 2019). Students made a wrong agreement i.e. plural subject used verb 1s and vice versa, the pronoun "I" used verb 1-s. This subject-verb agreement confuses students i.e. they do not know when to use verb 1-s or verb 1 only. Students possibly do not know that one letter in L2 (English) is meaningful. Conversely, one letter is meaningless in students' L1. The example of subject-verb agreement 
a. Climate change makes hot air is increasing

b. Medan havehas old building

Other errors such as tenses, compound noun, pair conjunction, infinitive, gerund, etc. are less error (less than 10 occurrences). It is noteworthy that tenses had small errors. The small number of errors regarding tenses shows that students' tenses knowledge is very good.

\section{L1-influence Error}

Graph 2 below shows that L1 affects students' L2 writing. There are four types of errors related to students' L1.

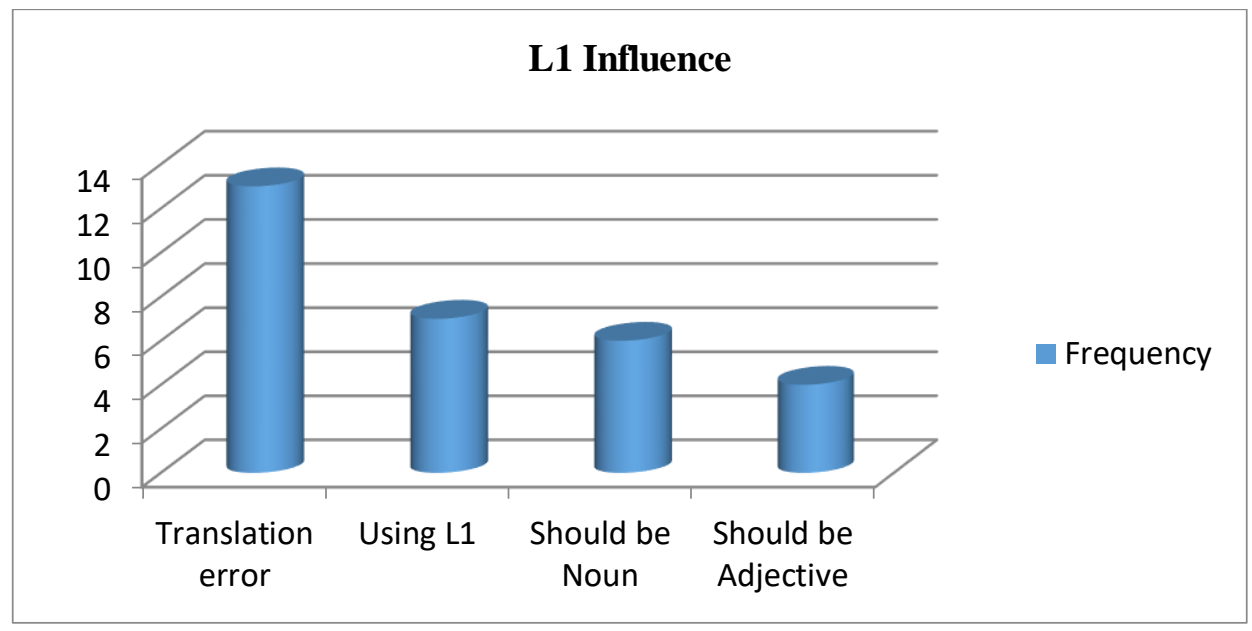

Graph 2. The Results of L1 Influence Errors

Translation error accounts for 13 occurrences. The translation error means that the vocabulary used is a direct translation from L1, for example "I justam the only child in our family". Thai students used literal translation (Phuket, 2015). Similarly, a study also revealed that $27,7 \%$ of students' error was word choice (Salima, 2012). The word choice and word-by-word translation cause inappropriateness. The translation error is caused by a translation machine e.g. Google translate that students used resulting inappropriate vocabularies.

Students still use L1 for vocabularies which are difficult to translate. Students do not italicize the L1 word. Since the mode of writing uses a computer which differs from paper-pen writing, it should be italic for a foreign language. The error is caused by the different modes of writing and no similar translation. For example, "it also has 'Saung Purbasari', if you want to eat lesehan in the situation of close to nature". The word 'lesehan' should be italic because it is L1. The errors of "should be noun and adjective" are 6 and 4 respectively. Students are not able to differentiate the morphological change of certain words because students' L1 does 
not have such morphological change. Inaccuracies are possibly caused by students' L1 (Henry \& Roseberry, 2007). The cause of error is inter-language. For example, in this moment you can find many eulturatcultures such as traditional dance.

\section{B. Learners' Perception}

The students' perception was garnered from questionnaires and interviews. 30 responses filled out the questionnaire. The perception included students' interest, students' difficulty, and efficiency of the program.

\section{Learners' Interest}

Based on the result of the questionnaire, students (36.7\%) were very interested and students (30\%) were interested in online writing exchange. Compared to conventional paper writing, students (48.3\%) chose very interesting and students (31\%) chose interesting. It shows that online writing exchange attracts students' interest. The majority of the students were interested in doing online writing. Their interest is triggered by the novelty method that they have never experienced before. Moreover, they write a post to other foreign students.

During the interview, all the interviewees said that they are interested in online writing because it can expand their friendship with other overseas students and they write a post to other foreign students. One of the interviewees responded, "I like online writing exchange because from that program I can practice grammar, writing, and get new friends". Similarly, the result of the questionnaire revealed that students like most were writing correspondence with overseas students (33.4\%), and followed by having new friends (20\%) and look for vocabularies for each initial post (20\%). Students' interest was also shown in the topic of each stage. As it is exhibited that no one chose 'none of them'. The most favorite topic was nature and culture (56.7\%). Students like to write nature and culture because their country is rich with cultures and natures. Furthermore, they want to promote their country's cultures and natures to their counterparts. The distinctive culture and nature between Indonesia and Japan was one of factor that gains students' interest, as an interviewee said, "from online writing exchange, I know their culture".

\section{Learners' Difficulty}

Based on the result of the questionnaire, students found difficulty in how to start writing $(56.7 \%)$ and followed by deadline length (13.3\%). Starting to writing becomes an obstacle for students. It is difficult for them to gain an idea of writing although the topic is provided in each stage. One interviewee stated "it is difficult to start writing. I need to think whether my topic of writing is interesting or not for them". From the interview, it showed that finding an interesting topic is difficult for students. Students' assignment is not only an English course but also other courses. As the interviewee said, "the deadline is short and sometimes I forget the due date because I have some other assignments". Some other assignments interfere with 
students in doing the online writing. Therefore, most students write a post on the last day of the deadline. Other difficulties in writing a post were grammatical errors (55.2\%) and incomprehensible posts (24.1\%). English is not as students' L2 but foreign language which they are still at the development of language. Students are still afraid of making grammatical errors. Grammar becomes their scary part of learning English although they have been exposed to grammar teaching since they were in secondary school. Afraid of making grammatical error makes writing is a difficult skill for them. The students are worried that their Japanese counterparts are not able to understand the post due to several grammatical errors. Word length also became the students' difficulty. As shown in the result of the questionnaire, most students prefer fewer words i.e. 100-200 words were the highest $(56.7 \%)$ and 200 300 words were the second-highest (40\%).

\section{Efficiency of The Program}

Regarding the efficiency of the program, students confirmed that online writing was important $(53.3 \%)$ and very important (30\%) for learning writing. It implies that online writing exchange plays a role in students' learning writing. It offers ample opportunity for students to practice writing and convey their ideas to their Japanese counterparts. One interviewee stated, "what I get from online writing exchange is to write better in English and convey my idea". It implies that students' writing skill improved because they think that their idea is understood by their counterpart. Students stated that the online writing exchange was efficient $(46.7 \%)$ in practicing writing skills. Students gain a better writing skill after the program. The last, students responded that they are rather capable of doing the online writing exchange (60\%). This response is related to students' difficulty. Students face several difficulties during online writing, they just doing online writing because of the assignments.

\section{CONCLUSION}

The mode of writing affects different students' errors. This study reveals that mechanical errors become the prominent errors. Mechanical error is not caused by inter-language because writing mechanics of students' L1 is the same as L2. For the grammatical error, students' L1 affects the error because the grammatical of students' L1 differ from L2. It is surprising that tenses have a small error which is different from previous studies. In sum, the mode of writing (online writing) causes different errors as this study found. Students' perception of online writing is positive. They consider the online writing is interesting and important for them in practicing writing. Although, students are still struggling to do the online writing exchange due to the deadline length and how to start writing. During online writing, students like to write a nature or a cultural topic (stage 2) because they want to promote their country to their Japanese counterparts. 


\section{ACKNOWLEDGEMENT}

This research was funded by PNBP of Brawijaya University. We would like to thank our two research assistants who have helped us. We also would like to thank our participants.

\section{BIBLIOGRAPHY}

Atmaca, C. 2016. Error Analysis of Turkish EFL Learners: A Case Study. Procedia Social and Behavioral Sciences, 232, $234-241$

Brown, H.D. 2001. Teaching by Principles: an Interactive Approach to Language Pedagogy $2^{\text {nd }}$ edition. New York: Longman

Deerajviset, P. and Harbon, L. 2014. E-learning in EFL Education in Thailand's Higher Education: The Role for Lecturers Making It Work. University of Sydney Papers in TESOL, 9, 37-63.

Dinamika, S. G. and Hanafiah, R. 2019. Syntactical Error Analysis on Report Text. JOALL (Journal of Applied Linguistics and Literature), 4 (2), 120-129

Doolan, S.M. 2017. Comparing Patterns of Error in Generation 1.5, L1, and L2 FirstYear Composition Writing. Journal of Second Language Writing, 35, 1-17

Ellis, R. 1994. The Study of Second Language Acquisition. Oxford: Oxford University Press

Ellis, R. and Barkhuizen, G. 2005. Analyzing Learner Language. Oxford: Oxford University Press

Fatimah and Masduki, H. 2017. Research Trends In EFL Writing In Indonesia: Where Art Thou? Journal of Teaching and Education, 07 (01), 89-98

Henry, A., \& Roseberry, R. L. 2007. Language Errors in the Genre-Based Writing of Advanced Academic ESL Students. RELC Journal, 38(2), 171-198. https://doi.org/10.1177/0033688207079692

Johnson, A.C., Wilson, J., Roscoe, R.D. 2017. College Student Perceptions of Writing Errors, Text Quality, and Author Characteristics. Assessing Writing, 34, 72-87.

Marina, V. and Snuviskinie. 2005. Error Analysis of Scientific Papers Written by Non-Native Speakers of English. Transport, 20(6), 274-279.

Naghdipour, B. 2016. English Writing Instruction in Iran: Implications for Second Language Writing Curriculum and Pedagogy. Journal of Second Language Writing, 32, 81-87.

Nation, I.S.P. 2009. Teaching EFL/ESL Reading and Writing. New York: Routledge 
Phuket, P. R. N. 2015. Understanding EFL Students' Errors in Writing. Journal of Education and Practice, 6(32), 99-106

Rendahl, M. and Breuch, L-A.K. 2013. Toward a Complexity of Online Learning: Learners in Online First-Year Writing. Computers and Composition, 30, 297-314

Salima, R. 2012. Measures of Eliminating EFL Students' Errors in Writing. Procedia - Social and Behavioral Sciences, 69, 318 - 327.

Straub, C. and Ill, E.V. 2015. Effects of Synchronous Online Writing Instruction for Students with Learning Disabilities. Journal of Special Education Technology, 30(4), 213-222

Said, M.N.H.M., Yahaya, N., Abdullah, Z., Atan, N.A., Zaid, N.M., 2016. The Nature of Student Group Online Interactions in Learning ICT Education. in Luaran, J.E., Sardi, J., Aziz, A., Alias, N.A. (eds.) Envisioning the Future of Online Learning: Selected Papers from the International Conference on eLearning 2015 (31-51). Singapore: Springer

Virtue, D. 2017. Increasing Students Interaction in Technical Writing Courses in Online Environments. Business and Professional Communication Quarterly, 80 (2), 217-235

Waes, L.V., Weijen, D.V., and Leijten, M. 2014. Learning to Write in an Online Writing Center: The Effect of Learning Styles on the Writing Process. Computers and Education, 73, 60-71

Wilcox, K.C., Yagelski, R. and Yu, F. 2014. The Nature of Error in Adolescent Student Writing. Reading Writing, 27 (6), 1073-1094. 